\title{
TU/e EN⿴HONE

\section{Plasma-assisted atomic layer deposition of Al2O3 moisture permeation barriers on polymers}

\section{Citation for published version (APA):}

Langereis, E., Creatore, M., Heil, S. B. S., Sanden, van de, M. C. M., \& Kessels, W. M. M. (2006). Plasmaassisted atomic layer deposition of Al2O3 moisture permeation barriers on polymers. Applied Physics Letters, 89(8), 081915-1/3. [081915]. https://doi.org/10.1063/1.2338776

DOI:

$10.1063 / 1.2338776$

Document status and date:

Published: 01/01/2006

\section{Document Version:}

Publisher's PDF, also known as Version of Record (includes final page, issue and volume numbers)

\section{Please check the document version of this publication:}

- A submitted manuscript is the version of the article upon submission and before peer-review. There can be important differences between the submitted version and the official published version of record. People interested in the research are advised to contact the author for the final version of the publication, or visit the $\mathrm{DOI}$ to the publisher's website.

- The final author version and the galley proof are versions of the publication after peer review.

- The final published version features the final layout of the paper including the volume, issue and page numbers.

Link to publication

\section{General rights}

Copyright and moral rights for the publications made accessible in the public portal are retained by the authors and/or other copyright owners and it is a condition of accessing publications that users recognise and abide by the legal requirements associated with these rights.

- Users may download and print one copy of any publication from the public portal for the purpose of private study or research.

- You may not further distribute the material or use it for any profit-making activity or commercial gain

- You may freely distribute the URL identifying the publication in the public portal.

If the publication is distributed under the terms of Article 25fa of the Dutch Copyright Act, indicated by the "Taverne" license above, please follow below link for the End User Agreement:

www.tue.nl/taverne

Take down policy

If you believe that this document breaches copyright please contact us at:

openaccess@tue.nl

providing details and we will investigate your claim. 


\title{
Plasma-assisted atomic layer deposition of $\mathrm{Al}_{2} \mathrm{O}_{3}$ moisture permeation barriers on polymers
}

\author{
E. Langereis, ${ }^{\text {a) }}$ M. Creatore, S. B. S. Heil, M. C. M. van de Sanden, and W. M. M. Kessels ${ }^{\text {b) }}$ \\ Department of Applied Physics, Eindhoven University of Technology, P.O. Box 513, 5600 MB Eindhoven, \\ The Netherlands
}

(Received 20 April 2006; accepted 3 July 2006; published online 25 August 2006)

\begin{abstract}
Thin $\mathrm{Al}_{2} \mathrm{O}_{3}$ films of different thicknesses $(10-40 \mathrm{~nm})$ were deposited by plasma-assisted atomic layer deposition on substrates of poly(2,6-ethylenenaphthalate) (PEN), and the water vapor transmission rate (WVTR) values were measured by means of the calcium test. The permeation barrier properties improved with decreasing substrate temperature and a good WVTR of 5 $\times 10^{-3} \mathrm{~g} \mathrm{~m}^{-2}$ day $^{-1}\left(\mathrm{WVTR}_{\mathrm{PEN}}=0.5 \mathrm{~g} \mathrm{~m}^{-2}\right.$ day $^{-1}$ ) was measured for a $20 \mathrm{~nm}$ thick $\mathrm{Al}_{2} \mathrm{O}_{3}$ film deposited at room temperature using short purging times. Such ultrathin, low-temperature deposited, high-quality moisture permeation barriers are an essential requirement for the implementation of polymeric substrates in flexible electronic and display applications. (c) 2006 American Institute of Physics. [DOI: 10.1063/1.2338776]
\end{abstract}

Successful application of flexible organic light emitting diodes (F-OLEDs) requires excellent moisture permeation barriers to minimize the degradation of the OLED device. ${ }^{1,2}$ Transparent moisture permeation barriers with an estimated water vapor transmission rate (WVTR) as low as $10^{-6} \mathrm{~g} \mathrm{~m}^{-2}$ day $^{-1}$ need to be deposited. ${ }^{1,3}$ Low deposition temperatures are required below the glass transition temperature of polymers and there is a strong preference for room temperature (RT) deposition because of process simplicity and compatibility with the OLED manufacturing process. ${ }^{4,5}$ Because the moisture permeation properties of a single layer barrier are eventually limited by the defect density of the layer, ${ }^{6}$ the deposition of multilayer structures is expected to be the path towards the WVTR requirements mentioned above $^{7-9}$ The multilayer structures will become most effective when the individual layers themselves have excellent permeation properties.

The atomic layer deposition (ALD) technique is known to produce densely packed, virtually defect-free, highly uniform, and conformal films and can therefore be used to deposit high-quality single layer permeation barriers. ${ }^{4,10,11}$ Groner et al. reported good permeation barrier properties $\left(\right.$ WVTR $=1 \times 10^{-3} \mathrm{~g} \mathrm{~m}^{-2}$ day $\left.^{-1}\right)$ of very thin $(10-25 \mathrm{~nm})$ $\mathrm{Al}_{2} \mathrm{O}_{3}$ films deposited from sequential trimethylaluminum (TMA) and water vapor exposures. However, they limited their deposition to a temperature of $120^{\circ} \mathrm{C}$ to have a short ALD cycle time $\left(60 \mathrm{~s}\right.$ at $\left.120^{\circ} \mathrm{C}\right){ }^{11}$ They also showed ALD of $\mathrm{Al}_{2} \mathrm{O}_{3}$ films at $33^{\circ} \mathrm{C}$, but this required $180 \mathrm{~s}$ of purging time to remove the residual water vapor, resulting in a total cycle time of $203 \mathrm{s.}^{12}$

The plasma-assisted ALD (PA-ALD) technique has the same growth characteristics as thermal ALD, but the use of $\mathrm{O}_{2}$ plasma radicals in the process enables deposition at room temperature without requiring long purging times. Furthermore, when admixing $\mathrm{N}_{2}$ gas to the $\mathrm{O}_{2}$ plasma, also $\mathrm{N}$-doped $\mathrm{Al}_{2} \mathrm{O}_{3}$ can easily be deposited by PA-ALD, which has been investigated previously for its permeation barrier properties. ${ }^{13}$

\footnotetext{
${ }^{a)}$ Electronic mail: e.langereis@tue.nl

${ }^{b)}$ Electronic mail: w.m.m.kessels@tue.nl
}

In this letter, we show the ability of PA-ALD in obtaining good $\mathrm{Al}_{2} \mathrm{O}_{3}$ moisture permeation barriers films at low substrate temperature (from RT to $100{ }^{\circ} \mathrm{C}$ ) on poly $(2,6$ ethylenenaphthalate) (PEN) substrates using short cycle times. A good WVTR of $5.0 \times 10^{-3} \mathrm{~g} \mathrm{~m}^{-2}$ day $^{-1}$ is obtained for a $20 \mathrm{~nm}$ thick film deposited at room temperature with a cycle time of $17 \mathrm{~s}$.

Thin $\mathrm{Al}_{2} \mathrm{O}_{3}$ films were deposited in a homebuilt deposition reactor by PA-ALD from sequentially exposing the substrate to TMA vapor and a remote $\mathrm{O}_{2}$ plasma. The deposition chamber was continuously purged by $\mathrm{O}_{2}$ resulting in a pressure of 7.5 mTorr. The PA-ALD cycle, used at all deposition temperatures, consisted of multiple TMA dosing (1 s each) injected from a trapped volume, $5 \mathrm{~s}$ purge, $2 \mathrm{~s} \mathrm{O}_{2}$ plasma, and $5 \mathrm{~s}$ purge. The plasma was created in a remote inductively coupled plasma source operated on the $\mathrm{O}_{2}$ background gas. The depositions were carried from RT up to $200{ }^{\circ} \mathrm{C}$ on $c$-Si substrates and up to $100{ }^{\circ} \mathrm{C}$ on PEN (DuPont Teijin Films, glass transition temperature $T_{g}=121^{\circ} \mathrm{C}$ ). Prior to deposition, the PEN substrates were ultrasonically cleaned in ethanol and were heated overnight at $70^{\circ} \mathrm{C}$ in the reaction chamber at a base pressure of $10^{-6} \mathrm{mTorr}$ to remove residual water in the polymer. The moisture permeation barrier properties of the films were determined by means of the calcium test, ${ }^{14}$ in which the change in transparency of a $100 \mathrm{~nm}$ thick $\mathrm{Ca}$ film was monitored in a controlled environment ( $T$ $=21{ }^{\circ} \mathrm{C}$ and $60 \%$ relative humidity) to determine the WVTR of the film.

The PA-ALD $\mathrm{Al}_{2} \mathrm{O}_{3}$ films were characterized on $c$-Si wafers and the results are reported in Table I. Two different TMA doses were used, i.e., undersaturated dosing (one TMA dose) and saturated dosing (five TMA doses), providing information about the influence of the chemical composition of the $\mathrm{Al}_{2} \mathrm{O}_{3}$ film on the barrier properties. During deposition, the $\mathrm{Al}_{2} \mathrm{O}_{3}$ thickness was determined by in situ spectroscopic ellipsometry (SE). As expected, the growth rate of the saturated PA-ALD growth is higher compared to undersaturated TMA dosing conditions. The growth rate increased for decreasing substrate temperatures, as reported previously for ALD of $\mathrm{Al}_{2} \mathrm{O}_{3} \cdot{ }^{15,16}$ Rutherford backscattering spectroscopy (RBS) showed that the mass density of the $\mathrm{Al}_{2} \mathrm{O}_{3}$ films was 
TABLE I. Properties of $\sim 30 \mathrm{~nm}$ thick $\mathrm{Al}_{2} \mathrm{O}_{3}$ films deposited at different temperatures on native oxide covered $c$-Si substrates using two different TMA dosing conditions in the PA-ALD cycle. The growth rate is determined from in situ SE; the mass density and film composition are determined from RBS. The first row gives the typical absolute errors on the results.

\begin{tabular}{lclll}
\hline \hline & $\begin{array}{c}\text { Deposition } \\
\text { temperature } \\
\left({ }^{\circ} \mathrm{C}\right)\end{array}$ & $\begin{array}{l}\text { Growth rate } \\
(\mathrm{nm} / \text { cycle })\end{array}$ & $\begin{array}{l}\text { Mass density } \\
\left(\mathrm{g} \mathrm{cm}^{-3}\right)\end{array}$ & $\begin{array}{l}\text { Composition } \\
\mathrm{Al}_{2} \mathrm{O}_{x}\end{array}$ \\
\hline Undersaturated & 25 & $0.12 \pm 0.005$ & $3.0 \pm 0.1$ & $3.60 \pm 0.05$ \\
& 50 & 0.11 & 2.9 & 3.40 \\
Saturated & 100 & 0.11 & 2.8 & 3.40 \\
& 200 & 0.097 & 2.9 & 3.34 \\
& 70 & 0.17 & 2.9 & 3.20 \\
& 200 & 0.13 & 3.0 & 3.14 \\
\hline \hline
\end{tabular}

virtually independent of deposition temperature, yielding an average value of $2.9 \pm 0.2 \mathrm{~g} \mathrm{~cm}^{-3}$. All the deposited $\mathrm{Al}_{2} \mathrm{O}_{3}$ films were oxygen rich and the amount of oxygen in the film increased for decreasing deposition temperature; however, the saturated growth condition resulted in a limited excess of oxygen in the film. Elastic recoil detection analysis showed that the films deposited by undersaturated and saturated TMA dosing contained 4 and 2 at. $\% \mathrm{H}$ for the deposition at $200{ }^{\circ} \mathrm{C}$, respectively. The hydrogen content increased at lower temperature up to 12 at. \% for undersaturated deposition at RT and indicates the presence of additional hydroxyl groups in the films.

RBS and x-ray photoelectron spectroscopy on a relatively thick $\mathrm{Al}_{2} \mathrm{O}_{3}$ film (500 cycles) deposited by undersaturated TMA dosing at $100{ }^{\circ} \mathrm{C}$ showed the same chemical composition on $c$-Si and PEN substrates, i.e., the $[\mathrm{O}] /[\mathrm{Al}]$ ratio was 1.7 . These results indicate that the bulk material properties of the film deposited by PA-ALD are not affected by the substrate material used.

Figure 1 shows the WVTR of $20 \mathrm{~nm}$ thin $\mathrm{Al}_{2} \mathrm{O}_{3}$ films as a function of deposition temperature in the range from RT to $100{ }^{\circ} \mathrm{C}$. The WVTR is found to improve for films deposited at lower temperatures and the saturated growth condition yields slightly better results. The trend with temperature is different than that reported for thermal ALD $\mathrm{Al}_{2} \mathrm{O}_{3}$ films prepared by TMA and $\mathrm{H}_{2} \mathrm{O}$ by Park et al. who observed that the barrier properties deteriorated for lower deposition tem-

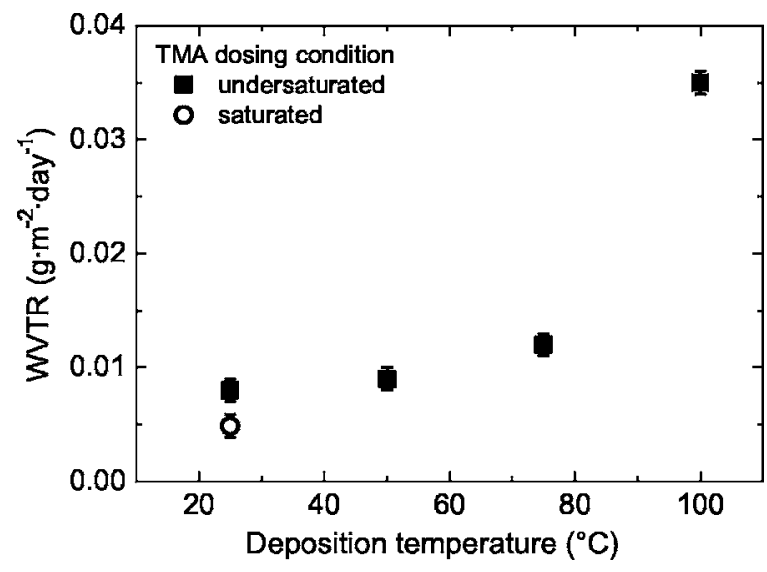

FIG. 1. Water vapor transmission rate (WVTR) of $20 \mathrm{~nm}$ thick PA-ALD $\mathrm{Al}_{2} \mathrm{O}_{3}$ films on PEN as a function of deposition temperature with undersatu-

rated and saturated TMA dosing conditions. ALD process using TMA and H $\mathrm{H}_{2} \mathrm{O}$, Park et al. reported a
Downloaded 14 Sep 2007 to 131.155.108.71. Redistribution subject to AlP license or copyright, see http://apl.aip.org/apl/copyright.jsp

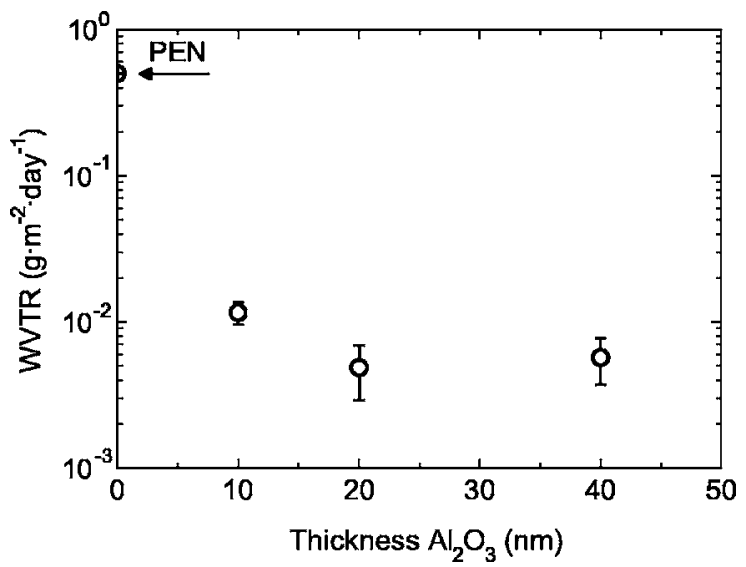

FIG. 2. Water vapor transmission rate (WVTR) of PA-ALD $\mathrm{Al}_{2} \mathrm{O}_{3}$ films on PEN as a function of film thickness. The films are deposited at room temperature with saturated TMA dosing conditions.

peratures $\left(80^{\circ} \mathrm{C}\right){ }^{4}$ The reason for the improvement of the WVTR for PA-ALD barriers is yet unknown but it can possibly be related to the observed increase in hydroxyl content in the $\mathrm{Al}_{2} \mathrm{O}_{3}$ films deposited at low temperatures (cf. Table I). It has been reported that the high polarizability of the (Al-) OH bonds of the film could obstruct water vapor permeation through the layer by means of $\mathrm{H}$ bonding with water vapor, ${ }^{17}$ although $\mathrm{H}_{2} \mathrm{O}$ dissociation at reactive hydrophilic sites is also suggested to occur. ${ }^{13}$ The mismatch of the coefficient of thermal expansion of $\mathrm{Al}_{2} \mathrm{O}_{3}$ and PEN might be another explanation as it can lead to stress generation at the interface when the sample is brought to RT after deposition at elevated temperature and, therefore, induce deterioration of the barrier properties. This effect, for which no morphological evidence is available yet, could be related to the difference in initial growth on the polymer surface between plasma-assisted and thermal ALD. Thermal ALD films are hypothesized to nucleate inside the polymer matrix, whereas a more discrete interface could be present for plasma-assisted ALD as the $\mathrm{O}_{2}$ plasma can create additional functional groups (e.g., $\mathrm{OH}$ ) on the polymer surface during the early stages of growth.

By adding $\mathrm{N}_{2}$ gas into the $\mathrm{O}_{2}$ plasma $\left(\left[\mathrm{N}_{2}\right] /\left[\mathrm{O}_{2}\right]=3: 2\right)$, $\mathrm{N}$-doped $(\sim 1$ at. $\% \mathrm{~N})$ stoichiometric $\mathrm{Al}_{2} \mathrm{O}_{3}$ was deposited and the nitrogen content in the film could be controlled by changing the plasma composition. The moisture permeation properties were briefly investigated for a deposition carried out at room temperature, resulting in a WVTR of $0.009 \mathrm{~g} \mathrm{~m}^{-2}$ day $^{-1}$ for a $20 \mathrm{~nm}$ thick film and did not show improved permeation barrier properties compared to the $\mathrm{Al}_{2} \mathrm{O}_{3}$ films. ${ }^{13}$ Preliminary investigation on AlN films deposited by PA-ALD at room temperature using a $\mathrm{N}_{2} / \mathrm{H}_{2}$ (3:2) plasma in the cycle showed negligible barrier properties.

The WVTR of the $\mathrm{Al}_{2} \mathrm{O}_{3}$ films as a function of thickness for deposition at RT is shown in Fig. 2. It is observed that a $10 \mathrm{~nm}$ thick $\mathrm{Al}_{2} \mathrm{O}_{3}$ film already shows very good barrier properties. The WVTR saturates for films thicker than $20 \mathrm{~nm}$ to the value of $5 \times 10^{-3} \mathrm{~g} \mathrm{~m}^{-2} \mathrm{day}^{-1}$, which is good for a single layer barrier, especially in comparison to the $0.40 \mathrm{~g} \mathrm{~m}^{-2}$ day $^{-1}$ for a magnetron sputtered $34 \mathrm{~nm}$ thick $\mathrm{AlO}_{x}$ film ${ }^{18}$ and to the $0.045 \mathrm{~g} \mathrm{~m}^{-2} \mathrm{day}^{-1}$ reported for plasma-enhanced chemical vapor deposited (PE-CVD) $\mathrm{SiN}_{x}$ films with a thickness of $130 \mathrm{~nm} .{ }^{19}$ Similarly, for the thermal ALD process using TMA and $\mathrm{H}_{2} \mathrm{O}$, Park et al. reported a to AIP license or copyright, see http://apl.aip.org/apl/copyright.jsp 
WVTR of $0.062 \mathrm{~g} \mathrm{~m}^{-2} \mathrm{day}^{-1}$ for a polyethersulfone film coated on both sides with $30 \mathrm{~nm} \mathrm{Al}_{2} \mathrm{O}_{3}$ film deposited $90{ }^{\circ} \mathrm{C}^{4}$ On the other hand, the obtained WVTR values for deposition at RT were in the same order as the results reported by Groner et al. by ALD at $120^{\circ} \mathrm{C}^{11}$ The improvement of barrier properties with respect to films deposited by PE-CVD can be related to the uniform and conformal ALD growth of the barrier layer on the polymer surface, which is porous, defective, and not particle-free. A saturation of the barrier properties with film thickness is, however, still observed. Plausible explanations are that the $\mathrm{Al}_{2} \mathrm{O}_{3}$ films are not completely pinhole-free or that "defects" on the polymer surface are not conformally "sealed" by the ALD film.

In summary, we have shown the feasibility of PA-ALD $\mathrm{Al}_{2} \mathrm{O}_{3}$ films at room temperature using short purging times in the order of seconds. The barrier properties of the $\mathrm{Al}_{2} \mathrm{O}_{3}$ films improved for lower deposition temperatures, which is promising from a manufacturing perspective of polymer substrates and for encapsulation of F-OLEDs at room temperature preventing device degradation. ${ }^{20}$ Saturation in barrier properties was observed for increasing film thickness, which suggests that the mechanism of water vapor permeation through the barrier/polymer is still defect controlled. The room temperature PA-ALD of $20 \mathrm{~nm}$ thick $\mathrm{Al}_{2} \mathrm{O}_{3}$ on PEN resulted in a good moisture permeation barrier resulting in a WVTR of $5 \times 10^{-3} \mathrm{~g} \mathrm{~m}^{-2} \mathrm{day}^{-1}$. In future experiments, the water and oxygen permeation mechanism will be further investigated focusing on the role of defects, nanoscale morphology, and the influence of the polymer substrate.

Note added in proof: After submission of this paper, Carcia et al. reported an excellent WVTR $<10^{-5} \mathrm{~g} \mathrm{~m}^{-2}$ day $^{-1}$ for $25 \mathrm{~nm}$ thick $\mathrm{Al}_{2} \mathrm{O}_{3}$ film deposited by thermal ALD on PEN. ${ }^{21}$ This experiment shows the potential of single layer barriers that can be obtained by ALD. Appropriate substrate cleaning and handling minimizing the amount of particles on the polymer surface is believed to be one of the key aspects in obtaining these superior barrier properties. For the experiments reported in the present work, no special care of substrate cleaning and handling was taken other than described in the text.

The authors would like to thank $\mathrm{H}$. van Hemmen and TNO Science and Technology for the calcium test measurements and Y. Tamminga and T. Dao from Philips Research Eindhoven for the RBS analysis. The Dutch Technology
Foundation STW is acknowledged for their financial support. The research of one of the authors (W.M.M.K.) has been made possible by a fellowship of the Royal Netherlands Academy of Arts and Sciences (KNAW).

${ }^{1}$ J. S. Lewis and M. S. Weaver, IEEE J. Sel. Top. Quantum Electron. 10, 45 (2004).

${ }^{2}$ J. N. Bardsley, IEEE J. Sel. Top. Quantum Electron. 10, 3 (2004).

${ }^{3}$ F. J. van Assche, R. T. Vangheluwe, J. W. C. Maes, W. S. Mischke, M. D. Bijker, F. C. Dings, M. F. J. Evers, W. M. M. Kessels, and M. C. M. van de Sanden, SID Int. Symp. Digest Tech. Papers 35, 695 (2004).

${ }^{4}$ S.-H. K. Park, J. Oh, C.-S. Hwang, J.-I. Lee, Y. S. Yang, and H. Y. Chu, Electrochem. Solid-State Lett. 8, H21 (2005).

${ }^{5}$ S. J. Yun, Y.-W. Ko, and J. W. Lim, Appl. Phys. Lett. 85, 4896 (2005).

${ }^{6}$ A. S. da Silva Sobrinho, G. Czeremuszkin, M. Latrèche, and M. R. Wertheimer, J. Vac. Sci. Technol. A 18, 149 (1999).

${ }^{7}$ G. L. Graff, R. E. Williford, and P. E. Burrows, J. Appl. Phys. 96, 1840 (2004).

${ }^{8}$ P. E. Burrows, G. L. Graff, M. E. Gross, P. M. Martin, M. K. Shi, M. Hall, E. Mast, C. Bonham, W. Bennett, and M. B. Sullivan, Displays 22, 65 (2001).

${ }^{9}$ M. S. Weaver, L. A. Michalski, K. Rajan, M. A. Rothman, J. A. Silvernail, P. E. Burrows, G. L. Graff, M. E. Gross, P. M. Martin, M. Hall, E. Mast, C. Bonham, W. Bennett, and M. Zumhoff, Appl. Phys. Lett. 81, 2929 (2002).

${ }^{10}$ A. P. Ghosh, L. J. Gerenser, C. M. Jarman, and J. E. Fornalik, Appl. Phys. Lett. 86, 223503 (2005).

${ }^{11}$ M. D. Groner, S. M. George, R. S. McLean, and F. Carcia, Appl. Phys. Lett. 88, 051907 (2006).

${ }^{12}$ M. D. Groner, F. H. Fabreguette, J. W. Elam, and S. M. George, Chem. Mater. 16, 639 (2004).

${ }^{13}$ A. G. Erlat, B. M. Henry, C. R. M. Grovenor, A. G. D. Briggs, R. J. Carter, and Y. Tsukahara, J. Phys. Chem. B 108, 883 (2004).

${ }^{14}$ P. C. P. Bouten, G. Nisato, P. J. Slikkerveer, H. F. van Tongeren, H. E. Itzhak, and P. van der Sluis, U.S. Patent No. 6,993,956 (7 February 2006).

${ }^{15}$ A. W. Ott, J. W. Klaus, J. M. Johnson, and S. M. George, Thin Solid Films 292, 135 (1997).

${ }^{16}$ A. Niskanen, K. Arstila, M. Ritala, and M. Leskelä, J. Electrochem. Soc. 152, F90 (2005).

${ }^{17}$ W. H. Koo, S. M. Jeong, S. H. Choi, W. J. Kim, H. K. Baik, S. M. Lee, and S. J. Lee, J. Phys. Chem. B 109, 11354 (2005).

${ }^{18}$ B. M. Henry, F. Dinelli, K.-Y. Zhao, C. R. M. Grovenor, O. V. Kolosov, G. A. D. Briggs, A. P. Roberts, R. S. Kumar, and R. P. Howson, Thin Solid Films 355-356, 500 (1999).

${ }^{19}$ M. Creatore, V. I. T. A. Lohmann, C. G. Klaasse Bos, A. C. M. Hamelink, M. M. Koetse, H. F. M. Schoo, and M. C. M. van de Sanden, Proceedings of the 48th Annual SVC Technical Conference and Smart Materials Symposium, Denver, Co, 23-28 April 2005 (Society of Vacuum Coaters, Albuquerque, NM, 2005), p. 163.

${ }^{20}$ K. Tsukagoshi, J. Tanabe, I. Yagi, K. Shigeto, K. Yanagisawa, and Y. Aoyagi, J. Appl. Phys. 99, 064506 (2006).

${ }^{21}$ P. F. Carcia, R. S. McLean, M. H. Reilly, M. D. Groner, and S. M. George, Appl. Phys. Lett. 89, 031915 (2006). 